\title{
Normal Width of Third Ventricle In Nepalese Population: Assessment By CT Scan
}

Amit Shrestha, ${ }^{1}$ Nikita Rajbhandari, ${ }^{1}$ Anand Shrestha, ${ }^{2}$ Bishika Pun ${ }^{2}$

'Department of Radiology, Nepal Medical College and Teaching Hospital, Jorpati, Kathmandu, Nepal, ${ }^{2}$ Department of Radiology, Om Hospital and Research Centre, Chabahil, Kathmandu, Nepal.

Introduction: Cerebral ventricular enlargement occurs as a natural aging process but also has been associated with many neurological disorders. Whether this enlargement is primary or secondary to these pathological conditions remains controversial. Objective of the study was to tabulate and create normal references values for maximum width of third ventricle in Nepalese population according to age group and gender.

Methods: MTW was determined in two hundred (112 males and 88 females) and age ranging between 1- 93 years who had normal Computed tomography scan (CT scan) of the head .The data collected was analyzed with statistical program IBM SPSS version 20.

Results: Measurements of MTW in both males and females of the normal groups revealed no significant difference. No significant difference in MTW was noticed till the age of 49 years. Significant differences were noticed between 49 - 93 years of age.

Conclusions: This study corroborated well with normal MTW values published in literatures from other parts of the world. However normal values specific to our local population becomes more relevant in interpreting CT scan of head in Nepal.

Keywords: cerebral atrophy; computed tomography scan; hydrocephalus; maximum width of third ventricle.

\section{INTRODUCTION}

Brain grows rapidly in early life and reaches its maximum weight by third decade and regression begins thereafter. ${ }^{1-4}$ But regression, which involves both cerebrum and cerebellum, tends to be slow at first, but it accelerates with advancing age, beginning usually by the seventh decade. ${ }^{5}$ The median and paramedian parts of the brain show regression early, and the third ventricle slowly begins to widen. In 1962, Yakovlev studying the "growth and maturation" of the nervous system, noted regression of the median nuclei of the thalami and widening of the third ventricle beginning by the fifth decade, and possibly before, and also a progressive diminution of the massa intermedia that joins the thalami. ${ }^{6}$ Morel and Wildi measured the volume of the ventricles of 423 fixed brains of individuals 55- 99 years old and noted a progressive increase in ventricular size up to the ninth decade. ${ }^{7}$ Knudson studied changes in ventricular size with aging by making casts of the ventricles of 185 fixed brains considered to be normal. ${ }^{8}$ There was considerable variation in size up to the seventh decade; thereafter the size increased rapidly, but one-third of the over 70 years group still

Correspondence: Dr. Amit Shrestha, Department of Radiology, Nepal Medical College \& Teaching Hospital, Attarkhel, Jorpati, Nepal. E-mail: austrygypsy@gmail.com, Phone: +977-9851056016. 
fell within the size range of $90 \%$ of the $20-40$ year group. ${ }^{8}$ The ventricles of males were larger than those of females, and the left lateral ventricles were usually larger than the right. $^{8}$ Cerebrospinal fluid (CSF) within the ventricle could be in excess or markedly reduced, and these could be the only sign of an intracranial or intraventricular disease. The linear dimensions of the $3^{\text {rd }}$ ventricle can be a key to some of these findings. The dimension of third ventricle can vary with various factors such as age, gender, body mass index (BMI) and various populations. ${ }^{9}$ The third ventricle, "ventricles tertiuscerebri," is one of four connected, cerebrospinal fluid-filled cavities of the human brain. ${ }^{10} \mathrm{It}$ is a median cleft between the two thalami, bordered inferiorly by the hypothalamus, communicates rostrally with lateral ventricle through interventricular foramina and caudally with fourth ventricle via cerebral aqueduct. The third ventricle develops from the central canal of the neural tube which in the future develops as the space of the diencephalon. ${ }^{11}$

Many studies by various authors have measured width of the third ventricle among both diseased and normal individuals using different imaging modalities like ultrasound, magnetic resonance imaging (MRI) and CT scan. Turner et al measured the width of the third ventricle among patients with multiple sclerosis and compared it against his control group using MRI, reported the width was much larger than the controls studied. ${ }^{12}$ The third ventricle width among preterm's were measured by Davies et al using cranial ultrasound, used in the diagnosis and assessment of ventricular enlargement in preterm infants and reported to have found no gender variation in his study. ${ }^{13}$ Schimmel et al showed significant enlargement in the length and width of the third ventricle among the infants with Trisomy 21 compared to the control group of unaffected newborns. ${ }^{14}$ Benedict et al compared the width of the third ventricle among patients of multiple sclerosis and normal subjects; the width among the control group was much smaller, as enlargement of the ventricles were observed in multiple sclerosis with associated neuropsychological impairment. ${ }^{15}$ According to Schochet, the brain undergoes many gross and histopathologic changes with advancing age, and also in various dementias, with regression of brain tissue leading to ballooning of the third ventricle and rounding of the angles of the lateral ventricles. ${ }^{16}$ Studies by LeMay attributed this ballooning of the third ventricle to a regression of the median nuclei of the thalami and a progressive diminution of the massa intermedia that joins them. ${ }^{17}$ Various studies by Andreasen et al, Kido et al and Huber et al clearly show an increase in the CSF spaces in dementia especially in Alzheimer's disease and Parkinson's disease. ${ }^{18-20}$ According to Corsellis and Creasy and Rapoport this was due to reduction in the size of nerve cells. ${ }^{21,22}$ Haaga reported ventricular enlargement to be a more sensitive indicator of cortical atrophy due to increasing age and dementias. ${ }^{23}$ Studies by McRae et al and Scott et al show larger lateral ventricles in epilepsy and depression respectively. ${ }^{24,25}$

The practice of using the reviewer's experience or observing a change in the shape of the ventricles can be very subjective, hence the need for normal values. This will enable early detection of changes due to intrinsic and extrinsic pathology. It is also important to monitor and evaluate response to therapy in patients being treated for hydrocephalus. Therefore the aim of this study was to assess the range of MTW in normal Nepalese population and evaluate the variation in size determined by the age and gender. Objective was to tabulate reference values for the same.

\section{METHODS}

Cross sectional study was performed in 200 patients (112 males and 88 females) at Nepal Medical College and Teaching Hospital, Jorpati, Kathmandu, Nepal between January and March 2016. Patients referred for plain CT scan of the head for symptoms ranging from headache, seizures, vomiting, loss of consciousness, ipsilateral weakness, and abnormal behavior to head trauma were included in this study. CT scan was performed in Toshiba Aquilion 64 multidetector CT scanner (Toshiba Medical System, Japan). Only cases interpreted as normal were included in the study. Exclusion criteria included presence of infarctions, intra or extra axial hemorrhage, mass, fracture of cranial vault or any other craniofacial injury which could have affected the measurements of MTW. Since chronic alcoholism leads to premature cerebral atrophy, such cases were excluded from the study. ${ }^{26}$ The patient was placed on the CT table and the head was centralized, supported and stabilized for correct alignment and to reduce motion artifacts. Volumetric plain $\mathrm{CT}$ scan of head was performed with angle of $15-20$ degrees to and one centimeter above canthomeatal line which represented the lowest tomographic section which passed through the base of skull. Tube voltage was 120 peak kilo voltage ( $\mathrm{KVp}$ ), tube current was 210 milliampere second (mAs) and slice thickness was 0.5 $\mathrm{mm}$. Cases were reviewed by a single radiologist with more than 8 years experience. Images were studied on $512 \times 512$ matrixes with fixed window width of 90 and window level of 40 to reduce intraobserver variability. The widest diameter of the third ventricle at the level of foramen of Monroe anterior to inter-thalamic adhesion (massa intermedia) was measured in millimeters $(\mathrm{mm})$ on each patient on axial images using an on screen linear electronic caliper (Figure 1).

Tables with age group, gender and corresponding 
normal MTW were tabulated using IBM SPSS Statistics 20 Version. Statistical differences, if any, in between different age group was calculated by independent $\mathrm{T}$ test. For evaluating the statistical significance of MTW between different ages Anova test was used. Comparisons with various other studies of MTW in normal populations were also made.

\section{RESULTS}

In our study, the youngest patient was 1 year old; whereas the oldest was 93 years (mean age 38.08 years). 112 $(56 \%)$ of the patients were male and the remaining 88 (44\%) were female. MTW increased with advancing age, however statistically significant increment only occurred after fifth decade onwards ( $p$ value $=0.001$ to 0.000 ). There was considerable variation in size up to the fifth decade; thereafter the size increased rapidly. MTW were greater in males as compared to females but the difference was not statistically significant ( $p$ value $=0.111$ ). The mean MTW of the total patients was $4.46 \pm 1.86$. The smallest MTW was $1.70 \mathrm{~mm}$ at and the largest MTW was $12.70 \mathrm{~mm}$.

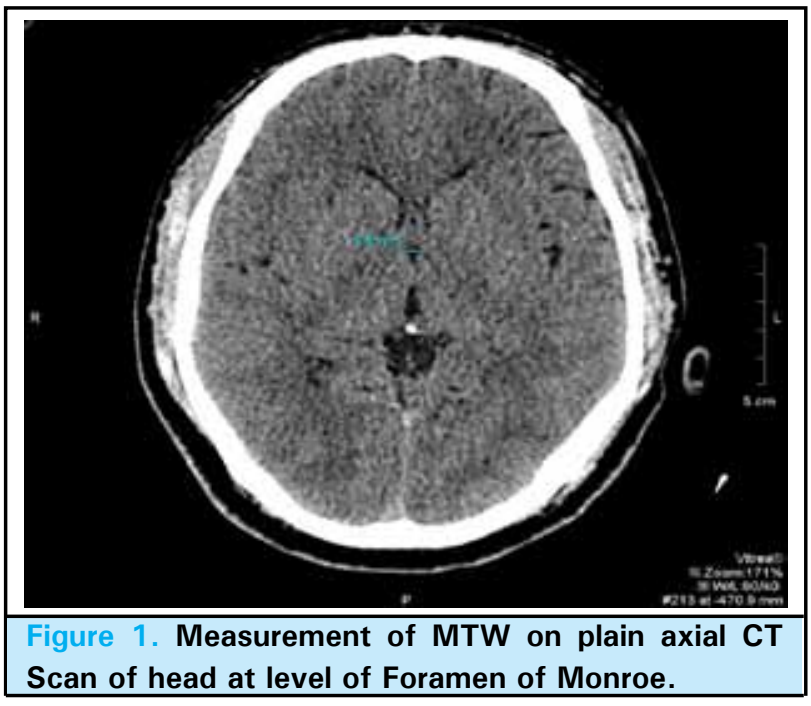

\begin{tabular}{|c|c|c|}
\hline Age range & Mean MTW (mm) & SD \\
\hline $0-9$ yrs & 3.1100 & 1.01154 \\
\hline $10-19$ yrs & 3.5037 & .93376 \\
\hline $20-29$ yrs & 3.8068 & .90820 \\
\hline $30-39$ yrs & 3.6351 & 1.03742 \\
\hline $40-49$ yrs & 4.4292 & 1.22420 \\
\hline $50-59$ yrs & 5.2955 & 1.23113 \\
\hline $60-69$ yrs & 5.2750 & 1.87705 \\
\hline $70-79$ yrs & 6.9333 & 2.24877 \\
\hline$>80 \mathrm{yrs}$ & 9.2000 & 2.51339 \\
\hline
\end{tabular}

The differences of MTW between the different age groups were statistically very significant with $p$-value of 0.000. However the differences in MTW among males and females of different age groups were not statistically significant (Table 2).

\begin{tabular}{|c|c|c|c|c|c|c|}
\hline \multirow{2}{*}{$\begin{array}{l}\text { Age } \\
\text { range }\end{array}$} & \multirow{2}{*}{$\begin{array}{c}\text { No. of } \\
\text { patients }\end{array}$} & \multicolumn{2}{|c|}{ Male } & \multicolumn{2}{|c|}{ Female } & \multirow{2}{*}{ p-value } \\
\hline & & MTW & SD & MTW & SD & \\
\hline $0-9$ & 10 & 2.66 & 1.078 & 3.56 & .795 & 0.172 \\
\hline $\begin{array}{c}10- \\
19\end{array}$ & 27 & 3.59 & .955 & 3.32 & .914 & 0.486 \\
\hline $\begin{array}{l}20- \\
29\end{array}$ & 44 & 3.91 & .927 & 3.68 & .892 & 0.404 \\
\hline $\begin{array}{c}30- \\
39\end{array}$ & 37 & 3.80 & 1.02 & 3.27 & 1.02 & 0.146 \\
\hline $\begin{array}{l}40- \\
49\end{array}$ & 24 & 4.83 & 1.05 & 3.94 & 1.28 & 0.074 \\
\hline $\begin{array}{l}50- \\
59\end{array}$ & 22 & 5.78 & 1.21 & 4.81 & 1.09 & 0.062 \\
\hline $\begin{array}{c}60- \\
69\end{array}$ & 16 & 6.40 & 2.44 & 4.60 & 1.10 & 0.060 \\
\hline $\begin{array}{l}70- \\
79\end{array}$ & 12 & 7.68 & 3.11 & 6.40 & 1.42 & 0.355 \\
\hline$>80$ & 8 & 9.96 & 2.95 & 7.93 & .95 & 0.304 \\
\hline
\end{tabular}

\section{DISCUSSION}

As discussed above, the width of the third ventricle may be the key findings in several disease processes and important in monitoring treatment of hydrocephalus. Due to its midline location, well defined regular oblong shape and innate contrast between the surrounding soft tissue and CSF, its measurements are more accurate and highly reproducible as compared to other ventricles.

Although principle aim of this study was to derive normal references values of MTW for Nepalese population, the data corroborated well with multiple similar studies from various parts of the world involving different races (Table 3). ${ }^{27-35}$ Finnish study conducted by Soininen et al in 1982 found MTW to be higher than rest of the studies probably due to the fact that the study included both normal control group and patients with Alzheimer's disease and multi infarct dementia. ${ }^{27}$

Two other studies in Caucasian race by Brinkman et al (in 1981) and Gawler et al (in London, 1975) showed mean MTW to be slightly higher than our population. ${ }^{28,29}$ However all three studies did not include gender dependent MTW. Studies in African population in Negroid race by Ahmed et al (between 2009 -12, Zaria - Nigeria) and Usman et al (between 2007 - 2012, 
West Nigeria) found MTW to be comparable to present study although it was slightly higher in latter study. ${ }^{30,31}$ This could be due to larger number of subjects in both studies, being 488 and 926 respectively. Interestingly, study by Zauhair et al (in 2009, Iraq) revealed MTW to be lesser in both males and females as compared to our study. ${ }^{32}$ Even though, the age range was comparable (10-69 years), their subjects were smaller in number (112). In more recently conducted study in similar region of Middle East, Moawia et al (in 2015 ,Saudi Arabia) with 152 study population, discovered MTW to be higher in both males and females than this study. ${ }^{33}$ Two studies in India by D'Souza et al (in 2007, Goa) and Mathew et al (in 2012, Punjab) compared well with present research. ${ }^{34,35}$ However the latter study was performed with MRI which probably explains higher values of the mean MTW.

This study has not only revealed that MTW increases with age and varies with sex, which has already been established by many previous literatures, but also points to the fact that it may also vary between different races. Therefore it stands to reason that normal references values of MTW extracted from our own local regional population becomes paramount whenever interpreting CT scan in the same population set. However, having stated the above and given the small number of our study subjects, it is still wise to follow general measurement guideline established way back in 1980 in study by Meese W et al, which summarizes that normal MTW on CT scan and MRI should be $<5 \mathrm{~mm}$ in children, $<7 \mathrm{~mm}$ in adults $<60$ years of age and $<9 \mathrm{~mm}$ in adults above 60 years. ${ }^{36}$

\begin{tabular}{|c|c|c|c|c|c|c|c|c|c|c|c|c|c|c|c|c|c|}
\hline \multirow{2}{*}{$\begin{array}{l}\text { Parameter } \\
\text { MTW(mm) }\end{array}$} & \multirow{2}{*}{$\begin{array}{l}\text { Soininen } \\
\text { et al }{ }^{27}\end{array}$} & \multirow{2}{*}{$\begin{array}{l}\text { Brinkman } \\
\text { et } \mathrm{al}^{28}\end{array}$} & \multirow{2}{*}{$\begin{array}{l}\text { Gawler } \\
\text { et } \mathrm{al}^{29}\end{array}$} & \multicolumn{2}{|c|}{ 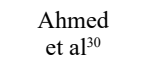 } & \multicolumn{2}{|c|}{$\begin{array}{l}\text { Usman } \\
\text { et } \mathrm{al}^{31}\end{array}$} & \multicolumn{2}{|c|}{$\begin{array}{c}\text { Zauhair } \\
\text { et }^{3 l^{32}}\end{array}$} & \multicolumn{2}{|c|}{$\begin{array}{l}\text { Moawia } \\
\text { et } \mathrm{l}^{33}\end{array}$} & \multicolumn{2}{|c|}{$\begin{array}{l}\text { D'Souza } \\
\text { et al }{ }^{34}\end{array}$} & \multicolumn{2}{|c|}{$\begin{array}{l}\text { Mathew } \\
\text { et al*35 }\end{array}$} & \multicolumn{2}{|c|}{$\begin{array}{l}\text { Present } \\
\text { Study }\end{array}$} \\
\hline & & & & $\mathrm{M} * *$ & $\mathrm{~F}^{* * *}$ & M & $\mathrm{F}$ & $\mathrm{M}$ & F & M & $\mathrm{F}$ & M & $\mathrm{F}$ & M & $\mathrm{F}$ & $\mathrm{M}$ & F \\
\hline Mean (mm) & 9.2 & 5.9 & 4.6 & 4.2 & 3.8 & 5.34 & 5.25 & 2.39 & 2.16 & 5.7 & 5.4 & 4.5 & 3.9 & 5.73 & 5.38 & 4.64 & 4.22 \\
\hline SD & \pm 2.71 & - & - & \pm 1.25 & \pm 0.8 & \pm 1.38 & \pm 1.32 & $\begin{array}{c} \pm \\
0.64\end{array}$ & \pm 0.57 & 1.54 & 1.68 & \pm 0.29 & \pm 0.17 & \pm 1.61 & $\begin{array}{c} \pm \\
1.33\end{array}$ & $\begin{array}{c} \pm \\
2.09\end{array}$ & \pm 1.50 \\
\hline
\end{tabular}

* Study with MRI measurements; rest with CT scan measurements

$* * \mathrm{M}=$ Male, ${ }^{* *} \mathrm{~F}=$ Female

\section{REFERENCES}

1. Von Braunmuhl A, A des Zentralnervensystems. In: Lubarsch H, Henke F, Rossie R, eds. Handbuch der Speziellen Pathologischen Anatomie and Histologie, vol. 13. Berlin:Springer Verlag,1957:337-539

2. Chernyshev SP. The weight of the human brain. In: Blinkov SM , Glezer II, eds. The human Brain in figures and tables. New York:Plenum, 1968:337

3. De Kaban AS ,Sadowsky BS. Changes in brain weights during the span of human life: Relation of brain weights to body heights and body weights. Ann Neurol Psychiatr1978;4:345-356

4. Pakkenberg HL, Voigt J. Brain weight of the Danes. Acta Anat(Basel) 1964;56 :97-307

5. Ellis RJ. Norms for some structural changes in the human cerebellum from birth to old age. J Comp Neurol 1920;32:1-35

6. Yakovlev PI. Morphological criteria of growth and maturation of the nervous system in man. Ment Retard 1961;39:3-46

7. Morel J, Wildi E. General and cellular pathochemistry of senile and pre senile alterations of the brain. In: Proceedings of the First International Congress of Neuropathology, vol2. Rome, 1952:347-374
8. Knudson PA, Veentriklernes S: Anatomisk normale Hjerner fra Voksne (thesis). Copenhagen. Odense, Denmark:Andeelsbogtykkeriet, 1958

9. Skullerud K. Variations in the size of the human brain. Influence of age, sex, body length, body mass index, alcoholism, Alzheimer changes, and cerebral atherosclerosis. Acta Neurol Scand Suppl 1985;102:1-94.

10. Berry M, Bannister LH, Scandring SM. Nervous system. In: Williams L, Lawrence H, Bannister LH, Martin MB, Collins P, Dyson M, Dussek JE, FergusonWJ. Grays Anatomy. Chruchill Livingstone, Edinburgh London, Melbourne and Newyork. 38th eds:1995;1202

11. Le T, Vikas V, Neil V. First aid for the USMLE Step I. The McGraw-Hill Companies Inc.USA. 20th eds. 2010;126. ISBN 978-0-07-163340-6. Aviliable on theURL: http:// en.wikipedia.org/wiki/Third_ventricle.

12. Turner B, Ramil N, Blumhardt LD, Jaspan T. Ventricular enlargement in multiple sclerosis: a Comparison of threedimensional and linear MRI estimates. Neuroradiology. 2001;43:608-

13. Davies MW, Swaminathan M, Chuang SL, BetherasF. Reference ranges for linear dimensions of the intracranial ventricles in preterm newborns. Arch Dis Child Neonatal Ed. 2000;82:218-23. 
14. Schimmel MS, Hammerman C, Bromiker R, Berger I. Third ventricle enlargement among new born infants with Trisomy 21. Pediatrics. 2006;117(5):e928-31.

15. Benedict RH, Bruce JM, Dwyer MG, Abdelrahman N, Hussein S, Weinstock-Guttman B et al. Neocortical atrophy, third ventricle width and cognitive dysfunction in multiple sclerosis. Arch Neurol. 2006;63(9):1301-6.

16. Schochet, S.S. Neuropathology of ageing. Neur. Clin. of N. Am. 1998;16(3):569-80.

17. LeMay M. Radiological changes of the ageing brain and skull. Am J Roentgenol. 1984;143(2):383-9.

18. Andreasen NC, Smith MR, CG, Dennert JW, Olsen SA. Ventricular enlargement in schizophrenia: definition and prevalence. Am J Psychiatry 1982;139(3):292-6.

19. Kido DK, Caire ED and LeMay M, Ekholm S, Booth H, Panzer R. Temporal lobe atrophy in patients with Alzheimer's disease: A CT study. Am J Neuroradiol 1989;10(3):551-5.

20. Huber SJ, Chakeres DW, Paulson GW, Khanna R. Magnetic resonance imaging in Parkinson's disease. Arch Neurol. 1990;47(7):735-7.

21. Corsellis, J.A.N. Ageing and the dementias. In: Blackwood W, Corsellis, J.A.N. eds. Greenfield's Neuropathology ( $3^{\text {rd }}$ ed.). Arnold London 1976:797-848.

22. Creasey H, Rapoport SI. The aging human brain. Ann Neurol.1985;17(1):2-10.

23. Naheedy MH. Normal CT and MRI anatomy of the brain. In: Haaga JR, Sartori DJ, Lanzieri CF, Zerhouni EA, eds. Computed tomography and magnetic resonance imaging of the whole body (3rd ed.). Missouri, Mosby;1994:75-102.

24. McRae DL. Radiology in Epilepsy. In: Vinken PJ, Brujn GW, eds. Newyork,Elsevier:1974:530-58.

25. Scott ML, Golden CJ, Ruedrich SC and Bishop RJ: Ventricular enlargement in major depression. Psychiatry Res. 1983;8(2):91-3.

26. García-Valdecasas-Campelo E, González-Reimers E, Santolaria-Fernández F, De La Vega- Prieto MJ, Milena-Abril A, Sanchez-Perez MJ et al. Brain atrophy in alcoholics: relationship with alcohol intake; liver disease; nutritional status and inflammation. Alcohol Alcohol. 2007;42(6):533-8.
27. Soininen M, Puranen M, Riekkinen PJ. Computed tomography findings in senile dementia and normal ageing. J Neurol Neurosurg Psychiatry. 1982;45(1):50-54.

28. Brinkman SD, Sarwar $M$, Levin $H$, Morris $H H 3^{\text {rd }}$. Quantitative indexes of computed tomography in dementia and normal aging. Radiology.1981;138(1):89-92.

29. Gawler J, Du Boulay GH, Bull JW, Marshal J. Computerized tomography (the EMI Scanner): A comparison with pneumoencephalography and ventriculography. J Neurol Neurosurg Psychiatry 1976;39(3):203-11.

30. Ahmed UH, Solomon ED, Sefiya AOK, Barnabas D, Abdullahi J, Olaniyan F. Third and fourth cerebral ventricular sizes among normal adults in Zaria-Nigeria . Sub-Saharan Afr J Med 2015;2:89-92

31. Usman JD, Zagga AD, Tadros AA, Yunusa G, Saidu SA, Ahmed $\mathrm{H}$ et al. Morphological variation of third ventricle using computerized tomography among different gender and age groups: A 5-year retrospectivestudy in Usmanu Danfodiyo University Teaching Hospital, Sokoto, North West Nigeria. Sahel Med J 2013;16:83-5.

32. Zauhair AJ, Fadhil AALK. C.T scan measurements of the lateral and third ventricles in Apparently normal Iraqi subjects. J Fac Med Baghdad 2009; 51(3):320-22.

33. Moawia G, Abdalrahim A, Amir A, Mosleh AR. Morphometric analysis of the brain ventricles in normal subjects using computerized tomography. Open J Radiol. 2015;5:13-9.

34. D'Souza e Dias Medora C, Natekar Prashant E. Morphometric study of the ventricular system of brain by computerized tomography. J Anat Soc India. 2007;56:19-24.

35. Mathew LS, Paul M, Bakshi S. Assessment of third ventricle with MRI: morphological variations among different gender and age group. Webmed Central Anatomy 2012;3(5):WMC003370

36. Meese W, Kluge W, Grumme T, Hopfenmtiller W. CT evaluation of the cerebrospinal fluid spaces of healthy persons. Neuroradiology 1980;19:131-6. 